\title{
The Wheat Problem
}

THE Twentieth Report of the Imperial Economic Committee, originally intended for presentation at the Ottawa Conference in 1931, which was eventually postponed, has been issued in the form of a survey,* without recommendations, of the present wheat position, with an analysis of the chief causeseconomic, technical, social, and political-contributing thereto, together with indications as to which are in all probability temporary and which of a more permanent character. The fact that over vast areas of land the growing of wheat, the primary foodstuff of the world, does not repay the cost of production is a problem of the first magnitude for the Empire and for the world in general, and it is evident that such a situation has been brought about by the interaction of a number of complex causes.

In the report a statistical treatment is made of the changes in price, production, acreage, yield, and international trade that have taken place since 1920, special attention being paid to the later years of the period. Figures for Russia are excluded on account of their uncertainty and the exceptional position occupied by Great Britain during the years under consideration.

Since 1921 the trends of prices of wheat and general commodities have been very similar; this suggests that the changes in wheat prices are not solely attributable to causes peculiar to wheat production or marketing. Production, although in excess of effective demand in recent years, is actually lower than that normally expected from the pre-War trend, so that the term 'over-production' is a relative one only. The re-entry of Russia into the export trade, however, has done much to intensify the disparity between supply and demand. As a result, at the end of the crop year 1930-31, curtailment in wheat production was taking place in all the principal

- Reports of the Imperial Economic Conference. Twentieth Report : The Wheat Situation, 1931. Pp. 121. (London: H.M. Stationery Office, 1932.) $6 d$. net. exporting countries except Canada and Russia. The expansion which had occurred during the previous nine years was due to an increase in area harvested, rather than to any changes in the average yield per acre, which for the world as a whole has not shown much variation. Biological and, particularly, mechanical improvements in the methods of wheat production during the post-War period have had far-reaching economic consequences, for the result has been an increased output at a lower cost of production of a commodity for which a corresponding increase in consumption was not obtained.

Comparison is made between the policies adopted by certain important exporting and importing countries, and, almost throughout Europe, State action has been taken with the view of raising internal wheat prices in the interest of local producers. The most significant and, at the same time, the most uncertain feature of the present situation, however, is Russia. The existence of a wheat-producing country and potential exporter of the magnitude of Russia, the policy of which is not directly related to the international level of wheat prices, introduces completely new economic considerations into the question and complicates the task of assessing the world's situation.

The outlook for the season 1931-32, as summarised by the International Institute of Agriculture, indicates that the total world's production, including Russia, is, on the whole, insufficient to cover the requirements of consumption, so that it will be necessary to draw upon the accumulated stocks which continue to depress the market, but, nevertheless, it is estimated that they will still remain heavy at the end of the current crop year.

The wheat problem is, however, fundamentally a general problem, and the removal of the obstacles which to-day impede the recovery of industrial life would go a long way towards bringing about an improvement in the wheat situation.

\section{Recent Excavations in British Honduras}

THE report of the first and second Marshall Field Archæological Expeditions to British Honduras * serves to point the moral that, in archæological investigation, it by no means follows that the outstanding site or the sensational discovery in the long run makes the most illuminating contribution to knowledge of the culture of the people under investigation.

The settlements explored by these expeditions in 1928 and 1929 were situated in a peripheral area of Maya culture, in which neither exceptional develop. ment nor an advanced standard in the arts of life could be expected; while in themselves they were not of sufficient importance to justify inclusion even in the rank of fourth class sites. Yet, being in part residential, they give a truer view of the life and customs of the people than do more imposing ceremonial centres. The material they have yielded will constitute a considerable contribution toward what is much needed, namely, the formulation of an ordered sequence of pottery types and styles within a defined cultural area, which will serve as a basis for systematic and intensive study of the cultural history of circum. jacent regions in an ever-widening circle. Toward this a beginning has now been made in the investigations undertaken, or projected, by the Carnegie Institu-

" "Archæological Investigations in the Southern Cayo District, British Honduras." By J. Eric Thompson. Field Museum of Natural History, Publication 301. Anthropological Series, vol. 17, No. 3. tion of Washington at Uaxactun (Guatemala) and the Field Museum of Chicago in north-central Honduras.

The sites investigated by the two expeditions, of which Mr. Eric Thompson was the leader, are situated in the Cayo district of British Honduras, on the western frontier, where it borders on Guatemala. The actual site of the excavations was twenty-five miles south-east of the town of El Cayo in the neighbourhood of the Mountain Cow Water Hole. Except for a scarcity of water, the site was admirably adapted to Maya settlement, having an abundance of game and a salubrious air owing to its height. In fact, these settlements are the highest cities in the "Old Empire' area, Hatzcap Ceel, described in this report, being probably as much as $2250 \mathrm{ft}$. above sea-level. The country being very broken, the inhabitants were practically cut off from cities to the south, such as Pusilha and Lubaantun, though only forty miles away. To the west and north-west-to Ixkun, about thirtythree miles, and Ucanal, twenty-seven miles awaythe country was easily traversed. Although it is not known with certainty which tribes inhabited this area when the Spaniards came, it is. probable either that they were Mopans, who are known to have occupied the country immediately to the west, or were closely allied to that people. It is suggested tentatively that in ancient times these Mountain Cow Water Hole area cities were inhabited by Chol-speaking Mayas.

No. 3259, VoL. 129] 